\title{
PYGOCEPHALOMORPH CRUSTACEANS FROM THE EARLY PERMIAN OF URUGUAY: CONSTRAINTS ON TAXONOMY
}

\author{
GRACIELA PIÑEIRO, ELIZABETH MOROSI, ALEJANDRO RAMOS \\ Departamento de Evolución de Cuencas, Facultad de Ciencias, Iguá, 4225, 11400, Montevideo, Uruguay. \\ fossil@fcien.edu.uy,elimor37@yahoo.com,aleramos@fcien.edu.uy \\ FABRIZIO SCARABINO \\ Museo Nacional de Historia Natural, 25 de Mayo, 582, 11000, Montevideo, Uruguay.fscara@gmail.com
}

\begin{abstract}
Hoplita ginsburgi comb. nov. (Fabre \& Huard) is described from the Early Permian Mangrullo Formation of Uruguay. It is a large to very large pygocephalomorph characterized by a combination of characters that includes the presence of a round carapace bearing short, anterolateral, spine-like processes and a posteriorly extended, V-shaped cervical groove. Other traits include well-developed angular or round pleomeral pleurae bearing terminal spine-like processes, a tail fan with large and rounded uropod exopod, lacking diaresis, a roughly trapezoidal telson that gives support to small lateral spines and a relatively large triangular caudal spine. This species is also distinguished by the presence of a putative, simplified endophragmal skeleton, a structure not previously described in pygocephalomorphs, but present in fossil and extant higher crustaceans, where its function, although not so well understood, has been related to support for the limb musculature. Sexual dimorphism appears in Hoplita with the recognition of gonopods in males and seminal receptacles in the females. The studied specimens include moulting exuvia distinct from live individuals. The status of Notocarididae, the only currently recognized Gondwanan family, was examined, as well as the strength of the characters previously recognized as diagnostic. The study of the Uruguayan pygocephalomorphs revealed that taphonomy is an important constraint for the recognition of inferred autapomorphic characters, making difficult the taxonomic assignation of newly discovered specimens. Therefore, the use of more complete diagnoses, based on the greatest possible set of characters, would provide a much-needed contribution to a better understanding of this extinct group of malacostracan crustaceans. Paleobiogeographic and paleoecological data are also given, based upon new information provided by the studied Uruguayan specimens.
\end{abstract}

Key words: Pygocephalomorpha, Lower Permian, taphonomy, systematics, Mangrullo Formation, Uruguay.

RESUMO - É descrita Hoplita ginsburgi comb. nov. (Fabre \& Huard) do Permiano Inferior (Formação Mangrullo) do Uruguai. H. ginsburgi é um pygocefalomorfo de grande porte apresentando uma combinação de caracteres que inclui uma carapaça arredondada, com processos espiniformes anterolaterais curtos, e um sulco cervical posteriormente estendido, em forma de V. Outras características incluem pleuras abdominais com expansões angulares ou arredondadas, bem desenvolvidas que ostentam processos terminais espiniformes, cauda com exopodito do urópodo grande e arredondado, diarese ausente, télson aproximadamente trapezoidal que dá apoio a pequenos espinhos laterais e um espinho caudal triangular relativamente grande. Esta espécie também se distingue pela provável presença de um esqueleto interno endofragmal simplificado, uma estrutura ainda não descrita em pygocefalomorfos, mas presente em crustáceos superiores fósseis e recentes, onde sua função, embora não tão bem entendida, tem sido relacionada como suporte para a musculatura apendicular. Dimorfismo sexual aparece em Hoplita com o reconhecimento de gonópodos em machos e receptáculos seminais nas fêmeas. Os espécimes estudados incluem exúvias, distintas dos indivíduos vivos. O status de Notocarididae, a única família gonduânica atualmente reconhecida, foi reavaliado, bem como o peso dos caracteres anteriormente reconhecidos como diagnósticos. O estudo dos pygocefalomorfos do Uruguai revelou que a tafonomia é uma importante restrição para o reconhecimento dos caracteres autapomórficos sugeridos previamente, dificultando a atribuição taxonômica de espécimes recém descobertos. Portanto, o uso de diagnoses mais completas, fundamentadas no maior conjunto possível de caracteres, proporcionaria uma contribuição necessária para uma melhor compreensão deste grupo extinto de crustáceos malacostracos. Com base em novas informações fornecidas pelos espécimes uruguaios estudados, dados paleobiogeográficos e paleoecológicos são igualmente discutidos.

Palavras-chave: Pygocephalomorpha, Eopermiano, taxonomia, sistemática, Formação Mangrullo, Uruguai.

\section{INTRODUCTION}

Pygocephalomorpha is a clade of fossil crustaceans chiefly represented in brackish and freshwater communities of the Late Carboniferous to Early Permian (Brooks, 1962; Schram,
1981) and achieving an apparently Pangeaic distribution by the beginning of the Permian (Taylor et al., 1998).

Brooks (1962) recognized three families within Pygocephalomorpha based chiefly on the presence or absence of anterolateral and lateral spines on the dorsal carapace. Thus, 
according to Brooks (1962), Pygocephalidae is characterized by the presence of both these spines, absent in the original description of Pygocephalus (Husley, 1857), but present in later descriptions (Schram, 1980). Tealliocarididae and Notocarididae lack these spines. Brooks (1962) suggested that the pleon was reduced and reflexed under the thorax in Notocarididae.

According to Brooks (1962), Pygocephalidae includes the genera Pygocephalus Huxley, 1857, Anthracaris Brooks, 1962, Mamayocaris Brooks, 1962 and Pseudotealliocaris Brooks, 1962. Tealliocarididae includes Tealliocaris Peach, 1908 and Pseudogalathea Peach, 1883. Notocarididae is represented by just two genera, Notocaris Broom, 1931 and Paulocaris Clarke, 1920. This arrangement was followed by Schram (1974a,b, 1979), but he gave more complete diagnoses of the taxa, adding some order to the species-level taxonomy of the group. Taylor et al. (1998) erected a new family, Tylocarididae from the Lower Permian of China to ally the species Tylocaris asiaticus Taylor, Shen Yan Bin \& Schram, 1998 and Fujianocaris bifurcates Taylor, Shen Yan Bin \& Schram, 1998. A phylogenetic analysis performed by Taylor et al. (1998) supported most of the taxonomic arrangements outlined by Brooks (1962), but it showed several interesting relationships that contrast with the traditional scheme, such as the exclusion of Pseudogalathea from Tealliocarididae. Therefore, Taylor et al. (1998) considered Tealliocaridae to include Tealliocaris woodwardi (Etheridge, 1877) and the several species of Pseudotealliocaris, which were previously considered by Brooks (1962) as members of Pygocephalidae.

Despite the fact that several taxa have been described from the Permian deposits of Brazil (Clarke, 1920; Beurlen, 1931, 1934; Mezzalira, 1952; Beurlen, 1953; Mezzalira, 1954; Pinto, 1960, 1971, 1972; Pinto \& Adami-Rodrigues, 1996) our knowledge of South American pygocephalomorphs is very sparce. Brazilian pygocephalomorph species were recovered from calcareous as well as shale strata of the Irati Formation, indicating a distinct distribution related to habitat preferences (Piñeiro, 2002). Liocaris huenei Beurlen, 1931 and Liocaris angusta (Beurlen, 1931) were always associated with the shallow, calcareous facies, but Paulocaris pachecoi (Clarke, 1920) and Pygaspis brasiliensis Beurlen, 1934 seem to be restricted to deeper areas of the basin, represented by the oil-shales of the Irati Formation.

The taxonomic classification of the Brazilian taxa became confused when both species of Liocaris and Pygaspis brasiliensis were placed by Brooks (1962) in synonymy with Paulocaris, without any rigorous arguments for such a conclusion. Brooks' family Notocarididae was erected by grouping Notocaris as the type genus, and Paulocaris thus ignoring the family Pygaspidae in which these taxa were previously placed (Beurlen, 1934). Perhaps this confusion could be justified on the basis that Notocaris dates from Broom (1931) while Pygaspis dates from Beurlen (1934). Pygaspidae could be available as a separate family if the genera prove to be different enough to justify that. Later,
Pinto (1972) and Pinto \& Adami-Rodrigues (1996) resurrected Pygaspis and Liocaris as separate taxa, evoking the presence of anterolateral spines in the carapace of Paulocaris, which are absent in both the former genera. To increase the taxonomic confusion, the status of Pygaspis and Notocaris, the type genera of the two only previously known Gondwanan families Pygaspidae (Beurlen, 1934) and Notocarididae (Broom, 1931) respectively, need to be revised because otherwise they could be synonymous (Pinto, pers. comm. 2010). All taxa and characters used in pygocephalomorph taxonomy are therefore in need of complete reevaluation (Schramm, pers. comm., 2010) and the present contribution takes the first steps toward this goal.

In contrast to the prolific reports of Brazilian pygocephalomorphs, Uruguayan reports have been sporadic and restricted to geological contributions that referred to indeterminate and fragmentary 'pygaspid remains' from the Magrullo Formation (Bossi \& Navarro, 1991; De Santa Ana \& Gutiérrez 2000; Pinto et al., 2000). However, recently this unit has yielded numerous, virtually complete specimens preserved as highly mineralized tri-dimensional small individuals and as bi-dimensional impressions and compressions of large individuals (Piñeiro, 2004, 2006; Piñeiro et al., in press). The latter types include spectacular moulting and in-copula soft-bodied pygocephalomorphs, as one might expect in Konservat-Lagerstätten (Piñeiro et al., 2012). In the present contribution, we recognize a new pygocephalomorph nomenclatural combination resulting from the revision of the taxonomic status of the African species Pygaspis ginsburgi Fabre \& Huard, 1967, thus increasing our knowledge about the fossil record of this group in Gondwana. Finally, we will focus on several prior taxonomic problems uncovered within the Pygocephalomorpha.

\section{GEOLOGICAL AND STRATIGRAPHIC SETTING}

The Mangrullo Formation is part of the Paraná Basin infilling (Zalán et al., 1990) extending over the territories of Brazil, Argentina, Paraguay and Uruguay. The Mangrullo Formation outcrops in northern and northeastern Uruguay, where several fossiliferous localities have been studied (Figure 1). The deposition of the Mangrullo Formation probably began after the end of the Late Carboniferous-Early Permian glaciations and consists of black or dark-grey oil-stained shales and grey to green siltstones showing both parallel and undulating lamination. These are intercalated with lenticular to massive beds of light to dark-grey partially silicified limestones of variable thickness. These limestones are delimitated by sharp-erosive surfaces with symmetric ripple marks, indicative of waves or oscillating currents in shallow water bodies.

In contrast to the marine environment suggested by previous authors for the Mangrullo Formation (Mackinnon et al., 1982; Bossi \& Navarro, 1991; De Santa Ana \& Gutiérrez, 2000), Piñeiro $(2004,2006,2008)$ assumed this unit as deposited in standing fresh water to brackish conditions. This 


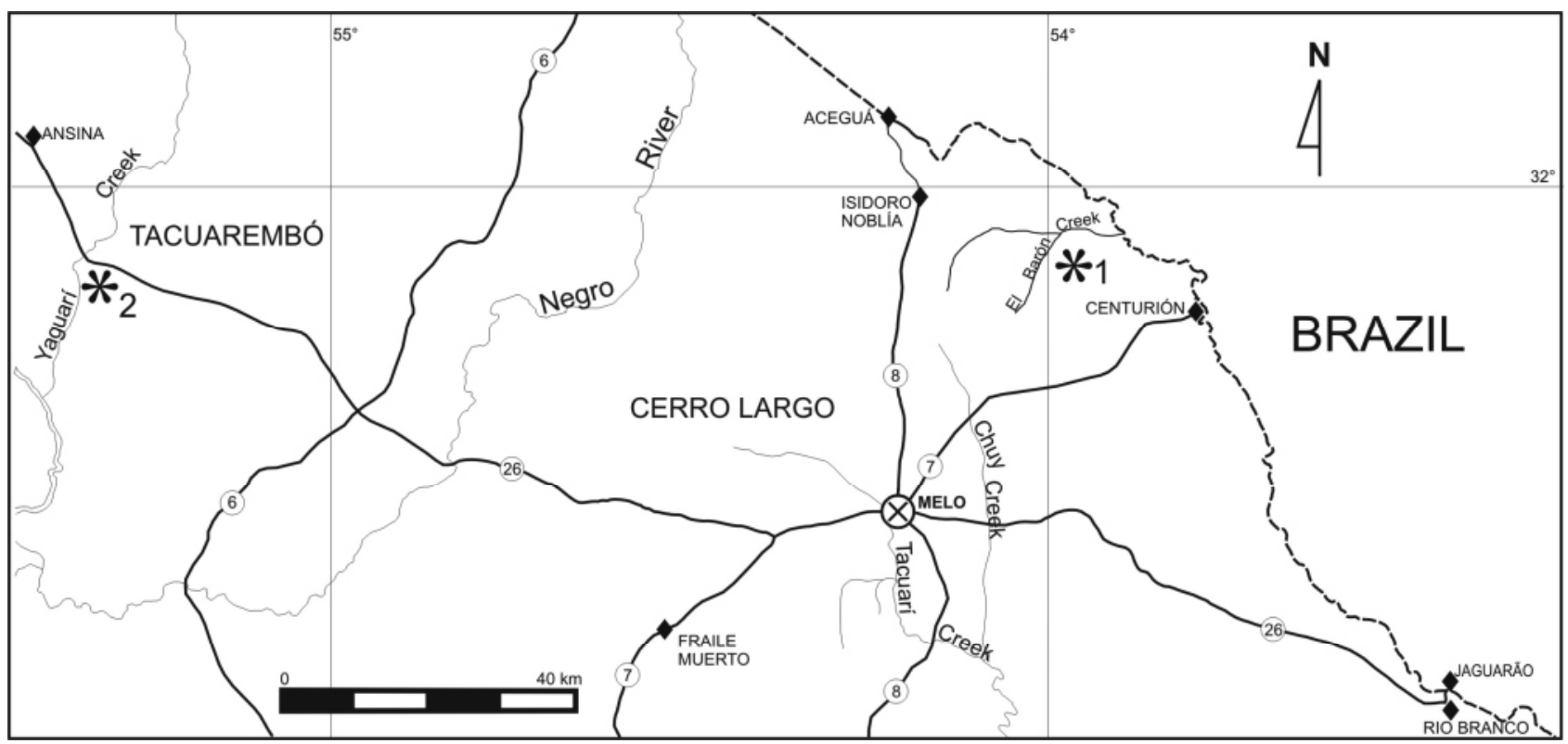

Figure 1. Map showing outcrops (asterisks) of the Early Permian Mangrullo Formation (Norte Basin, Northeastern Uruguay), where pygocephalomorph crustaceans were found.

hypothesis was supported by the absence of representative taxa of typical marine communities. New data (Piñeiro et al., 2012) indicates temporary hypersaline conditions for the strata containing pygocephalomorph crustaceans associated with mesosaur reptiles and the trace fossil Chondrites Anderson, 1976 comprising a very peculiar, low diverse community.

Pygocephalomorphs from the limestones are variously distorted, but they are invariably preserved as threedimensional specimens. This suggests sudden burial and rapid mineralization of the carcasses. In contrast, the specimens from the shales are compressed and bi-dimensionally preserved. This seems to indicate that time-averaging processes were at work. Spectroscopic analyses for mineralogical composition failed to reveal the presence of calcium carbonate in the dorsal carapace of the compressed specimens, but calcium carbonate and silica are the most abundant elements in the preserved tri-dimensional specimens. However, in both deposits, the mineralogical spectrum from the specimens and the surrounding sediment was similar.

The shale was deposited under anoxic bottom conditions (Bossi \& Navarro, 1991; Piñeiro, 2002, 2004, 2006; Piñeiro et al., 2012) established in the basin as a consequence of increased stratification of the water column in a similar fashion to that suggested for the Brazilian Irati Formation (Beurlen, 1957; Runnegar \& Newell, 1971). These conditions could thus explain the total absence of benthic taxa. Anoxic bottom conditions for the bituminous layers of the Mangrullo Formation are also supported by the presence of the ichnogenus Chondrites, a trace fossil known to have been produced by organisms adapted to life in such environments (Bromley \& Ekdale, 1984; Piñeiro, 2002, 2006). Increased aridity was evidenced by palinological data from the oil-shale facies (Piñeiro et al., 1998) and the presence of gypsum crystals (Piñeiro et al., in press).
The Mangrullo Formation is considered to be the stratigraphic equivalent of the Brazilian Irati and the South African Whitehill formations (Daemos \& Quadros, 1970; Oelofsen \& Araújo, 1983; Bossi \& Navarro, 1991; Piñeiro, 2002), mainly based on the presence of mesosaurids and pygocephalomorph crustaceans. The Mangrullo Formation was recently suggested to be Early Permian in age, based upon the presence of early representatives of the Gangamopteris flora (Piñeiro, 2006) also described by Oelofsen (1981) in the South African Whitehill Formation. An Early Permian age for the Mangrullo Formation is also supported by the presence of the fish trail Undichna insolentia Anderson, 1976 (Piñeiro, 2006) which was regarded to have a Late Carboniferous to Early Permian distribution (Anderson, 1976). In addition, recent radiometric analyses of bentonitic levels from both the Irati and the Mangrullo formations suggested an Artinskian age for these units (Basei et al., 2004; De Santa Ana et al., 2006; Santos et al., 2006). An Artinskian age for the Mangrullo and Irati formations is consistent with biostratigraphic data provided by their vertebrates (acanthodians and mesosaurids), invertebrates (pygocephalomorph crustaceans) and plants (Premaor et al., 2006).

\section{MATERIAL AND METHODS}

The materials described herein are housed in the Collection of Fossil Invertebrates of the Facultad de Ciencias of Uruguay (FC-DPI). The studied specimens were collected from both oil- shale and limestone deposits of the Mangrullo Formation. They were preserved as dorsoventrally or ventrodorsally compressed individuals, as well as in a three-dimensional form, allowing the exposition of the dorsal, lateral and ventral morphologies. Excepting for the latter, most specimens consist of part and counterpart of the same individual, collected after 
mechanical splitting of the laminated shale. Other isolated specimens could have been originally parts or counterparts of a single individual, but they were naturally separated by weathering of the deposits. Several of the specimens retained part of the chitinous cuticle replaced by pyrite precipitation. Carapaces were slightly to not mineralized during life, as the sternal morphology can be seen from dorsally preserved compressed individuals. This is a common feature found in fossil invertebrates that lack highly mineralized exoskeletons (Brooks, 1962). This condition was corroborated by SEM spectroscopy analyses which failed to detect calcium carbonate or other reinforcing minerals in the specimens, but registered in some levels of the unit (Piñeiro et al., 2012). Part of the soft anatomy was preserved by phosphatization. Internal organs can be recognized as dorsal or ventral in origin due to the splitting of the slabs exposing different internal levels. Three-dimensional preservation is restricted to coarser, sandy limestone levels, where specimens expose only the external surfaces. Specimens of the Brazilian genera Pygaspis and Liocaris (curated in MPI-UFRGS and MCN-PI), were also examined and compared.

Institutional abbreviations. FC-DPI, Departamento de Paleontología, Facultad de Ciencias, Montevideo, Uruguay; MPI-UFRGS, Museu de Paleontologia, Universidade Federal do Rio Grande do Sul, Porto Alegre, Brazil; MCN-PI, Seção de Paleontologia, Museu de Ciências Naturais, Fundação Zoobotânica do Rio Grande do Sul, Porto Alegre, Brazil.

\section{SYSTEMATIC PALAEONTOLOGY}

\author{
Subphylum CRUSTACEA Pennant, 1777 \\ Class MALACOSTRACA Latrielle, 1802 \\ Order PYGOCEPHALOMORPHA Beurlen, 1930 \\ Hoplita gen. nov.
}

Synonymy. Pygaspis sensu Fabre \& Huard, 1967, non Beurlen, 1934

Type species. Pygaspis ginsburgi Fabre \& Huard, 1967. Derivation of name. Hoplon (Greek) shield used by Spartan warriors, making reference to the armored shape of the thoracic somites.

Diagnosis of the genus. Large pygocephalomorphs (average length of adults over $30 \mathrm{~mm}$ ), distinguished by a round carapace that bears broad-based, short, anterolateral processes; surface of carapace finely granulated under magnification and with coarsely-pitted ornamentation around cervical groove; cervical grooves more deeply incised at their initial transverse trajectory, terminating in a slightly marked, roughly V-shaped posterior contact, approximately at the level of the second thoracic somite; thoracic somites sub-quadrangular with thick lateral walls, with the eighth segment broader than the preceding; putative axial cephalic and thoracic endophragmal skeleton present, consisting on longitudinal axial sternal projections (apodemes) that broaden and meet (but do not fuse) at the middle point of each segment; angled or round pleonal pleurae, bearing lateral spine-like projections which are more evident in large individuals.

Occurrence. Early Permian Mangrullo and Whitehill formations of Uruguay and South Africa, respectively.

Remarks. Fabre \& Huard (1967) described Pygaspis ginsburgi from the Upper Dwyka Shales of South Africa and figured it as having quadrate thoracic somites with axial anterior and posterior projections and long spine-like pleural processes on the pleon. Taking into account these anatomical features, Pinto (1971) considered this species different from Pygaspis brasiliensis and very similar to Notocaris tapscotti Broom, 1931 from the same unit, unless the described particular spine-like processes of the pleon are a taxonomic, rather than a taphonomic, attribute. After Pinto (1971), the taxonomic position of $P$. ginsburgi remained contentious, and no useful descriptions of new specimens were provided. The study of well preserved pygocephalomorph specimens from the Mangrullo Formation confirmed the particular thoracic features described by Fabre \& Huard (1967) for $P$. ginsburgi, as well as the presence of pleonal pleurae bearing spine-like projections. These attributes make $P$. ginsburgi significantly different from Pygaspis and all other known pygocephalomorph taxa, and justify its placement in the new genus Hoplita erected herein.

Hoplita ginsburgi (Fabre \& Huard, 1967) comb. nov. (Figures 2-12)

Diagnosis. As for the genus.

Materials. FC-DPI 4826, 4515, 4599, 4397, 4512, 4961, 4187, 4493, 4962, 4489, 3553, 4419, 4950, 3491, 3732, 4838, 4518, 4959, 4956, 3817, 3803, 4824, 4383, 4345, 3809, 3725, 3930, 3542,3559 .

Locality and horizon. The Uruguayan specimens come from several localities of the Mangrullo Formation at Tacuarembó and Cerro Largo County. These were associated with articulated and disarticulated mesosaur material and the trace fossil Chondrites.

Description. Hoplita ginsburgi comb. nov., attained a maximum length of $65 \mathrm{~mm}$ in mature individuals, which is large for members of the Pygocephalomorpha. Hoplita is represented by several virtually complete specimens preserved three-dimensional and compressed, dorsally and ventrally. The carapace outline is not well-marked in most specimens, probably because it was a very thin and delicate structure. Often the margins were disturbed or invisible due to lateral underfolding. Nevertheless, in some well-preserved, dorsoventrally compressed individuals the carapace outline was round and almost transparent, covering all the thoracic somites (Figure 2). In three-dimensional specimens the carapace outline appears cylindrical. It could have been connected to the cephalothorax just anteriorly, because in several specimens the posterior end of the carapace lifts away and is displaced laterally. The anterior margin of the carapace is almost straight, although in some specimens it appears to be 
slightly excavated lateral to the rostrum, thus enhancing the expression of short and broad-based anterolateral triangular processes (Figure 3). The rostrum is a short and triangular structure, apparently not falciform, which forms a joint with the anterior margin at its middle point, as shown by specimens preserved in ventral view. Dorsally, the rostrum bears a low medial ridge that does not reach the cervical groove (Figures 2, 3). Dorsal gastric or hepatic spines, as well as branchiostegal serrations are absent. The stalked eyes can be observed in some specimens. They are relatively large and positioned dorsal to low and irregular ridges extending parallel and oblique to the anterior margin of the carapace. These ridges are interpreted as the cephalic portions of the internal skeleton (Figure 3B). The cervical groove is moderately to deeply impressed anteriorly, but posteriorly the groove becomes a weak, almost imperceptible line, crossing the carapace obliquely to form a roughly $\mathrm{V}$-shaped axial contact at the level of the posterior margin of the second thoracic somite (Figures 2B, 4). Laterally, the groove splits into anterior and posterior branches. The anterior branch is longer. It reaches the anterior margin. The shorter posterior branch delimits an area that is usually ventrally folded. Ornamentation consists of fine punctate areas to coarser irregular pustules, which can be observed around the cervical groove in some wellpreserved specimens (Figure 4). The posterior margin of the carapace is weakly anteriorly excavated and dorsally arched to accommodate the pleon. It bears a well-defined but short thickening. The protocephalon bears the stalked eyes and two pairs of antennae. The antennal scale is rounded and large. It frequently hides the morphology of the antennal peduncle. Mandibles and apparently two pairs of maxillipeds can be distinguished in some specimens (Figures 5A-B), but their fine morphology is difficult to discern. Anterior to the putative maxillipeds and posterior to the eyes some specimens show the presence of medially positioned small pits (Figure 5). These could be related to the existence of a "dorsal organ", a structure previously reported in some crustacean groups whose function is controversial (Martin \& Laverack, 1992). The dorsal organ has been related to the presence of salt glands. If so, its presence in Hoplita could be reasonable. There are eight roughly quadrangular thoracic somites, each one bearing biramous pereiopods and delimitated by

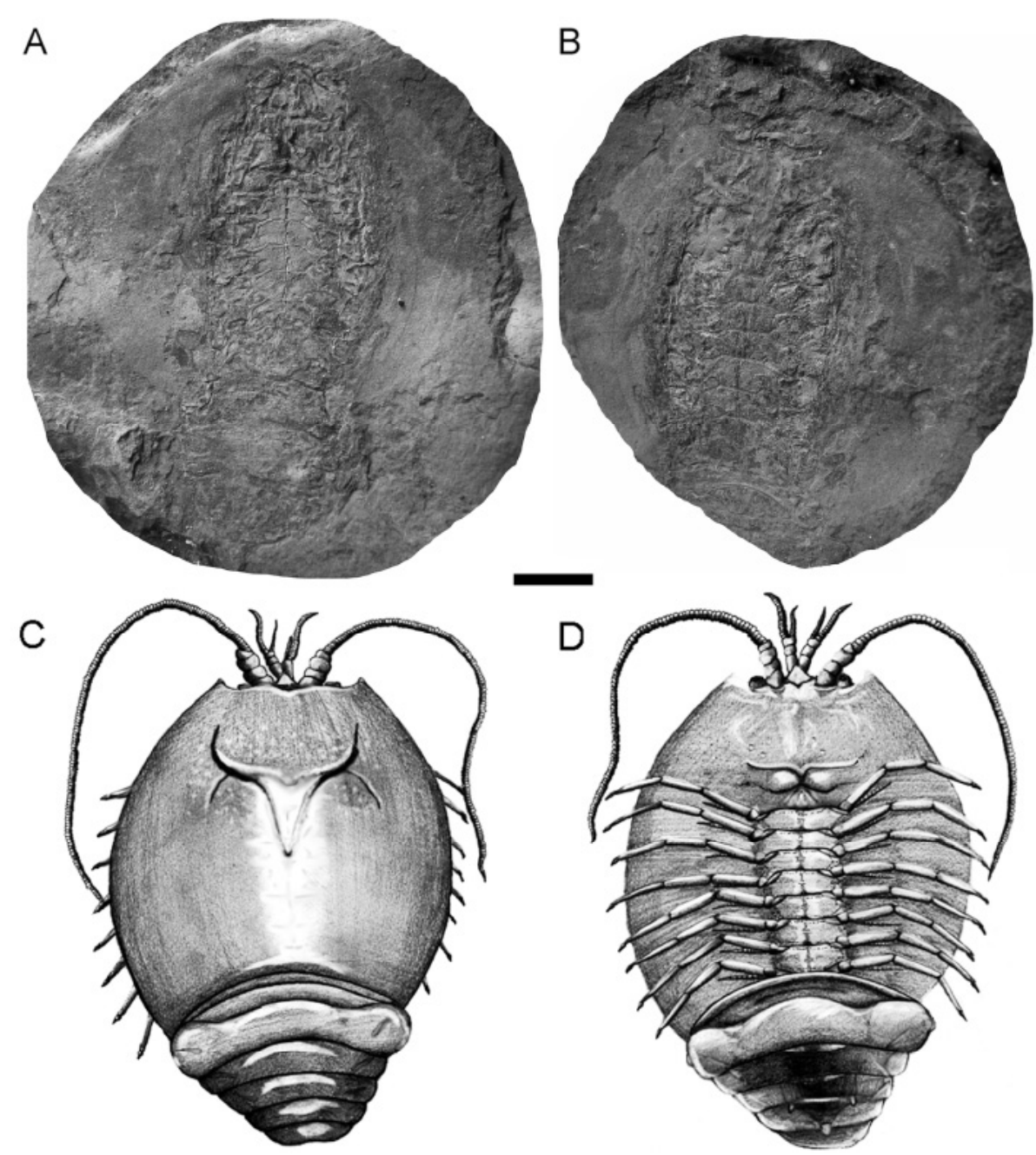

Figure 2. Hoplita ginsburgi comb. nov. General morphology. A-B, FC-DPI 4826, part and counterpart of an almost complete individual in dorso-ventral view, the presence of the endophtragmal skeleton and a round carapace can be well easily observed; B-C, composite reconstructions in dorsal and ventral views, respectively. Scale bar $=5 \mathrm{~mm}$. 
unfused, highly sclerotized lateral and transverse partitions, thus forming a reinforced, but flexible thoracic region. The first sternite is subtriangular and notably smaller than the succeeding, while the most posterior is conspicuously the largest of the series in most of the examined individuals (Figures 2, 3). Some specimens show clearly that the thick lateral walls of each somite meet at the transverse midline of the segment, but they do not fuse, as also occurs, as already noted, with the transverse tagmal partitions that remain unfused at the midline (Figure 6). This suggests the presence of membranous articulations, as was suggested for Anthracaris by Brooks (1962). However, they also could represent the preservation of moulting exuvia, which thus, might be easily differentiated from living individuals. Additionally, the most conspicuous characteristic of this taxon is the presence of a probable cephalic and thoracic endophragmal skeleton, which is clearly visible in compressed individuals and moulds, but it can be also detected in some three-dimensionally preserved specimens (Figures 7-9). In the latter, the elements of this internal skeleton could be easily mistaken for a mid dorsal carina, but a more careful observation demonstrates clearly that it is not a continuous ridge but a discontinuous structure (Figures $8 \mathrm{G}-\mathrm{H}$ ). The endophragmal skeleton is known to be well developed in fossil and extant decapods and "mysidaceans" (Taylor et al., 2001; Secretan, 2002), but it has not been described for any other pygocephalomorph. However, some specimens of Anthracaris and Mamayocaris figured by Brooks (1962) seem to display a similar thoracic structure to that found in $H$. ginsburgi comb. nov., but he denied the presence of this kind of skeleton in the referred North American taxa. The putative endophragmal skeleton of Hoplita consists of apparently inward anterior and posterior projections from successive thoracic sternites, which seem to approach each other (but do not fuse) at the middle central point of each somite (Figures 7-9). The function of these endoskeletal structures, which are well displayed along the eight thoracic somites and which seem to be continuous with other apodema seen
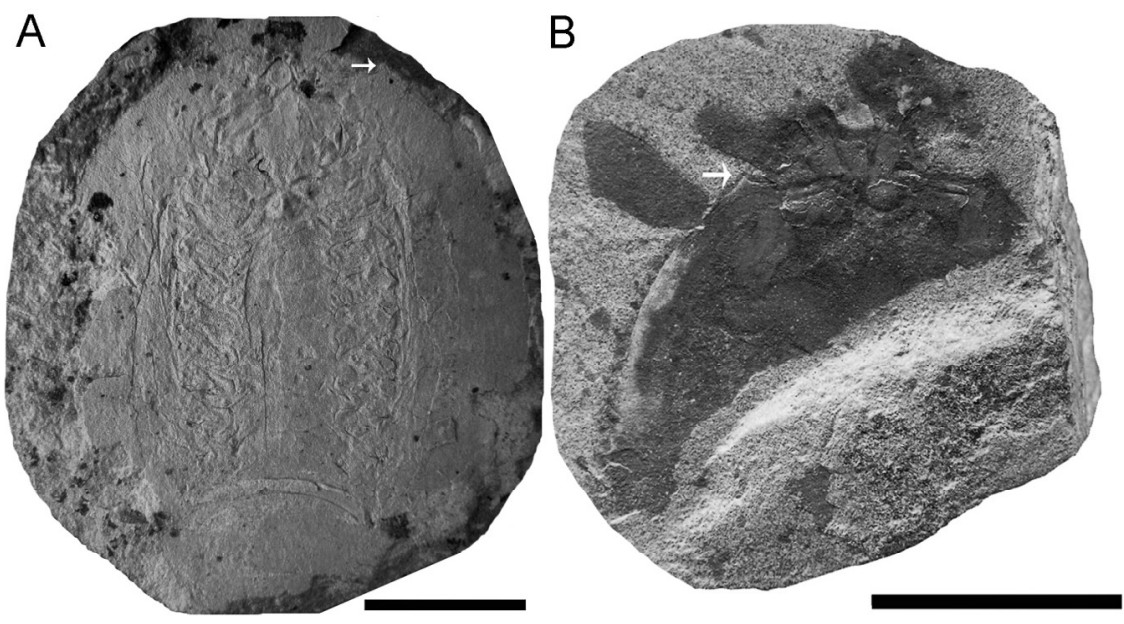

Figure 3. Hoplita ginsburgi comb. nov. Carapace outline. A, FC-DPI 4187, part of a specimen preserved as part and counterpart of the same individual; B, FC-DPI 4493, incomplete, anteriormost region of a well preserved specimen. Both materials show clearly the round-shaped carapace bearing anterolateral stout and triangular processes (white arrows). Scale bars $=10 \mathrm{~mm}$.

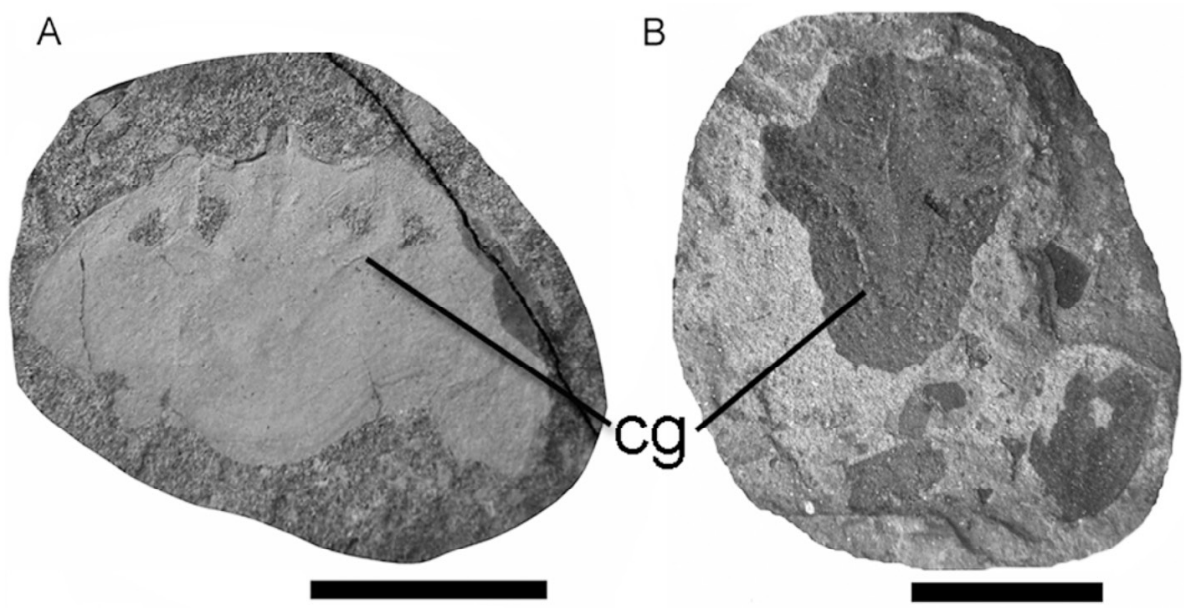

Figure 4. Hoplita ginsburgi comb. nov. Ornamentation. A, FC-DPI 4962, B, FC-DPI 4489, incomplete well preserved specimens preserving the anteriormost region of cephalothoracic carapace and cervical groove $(\mathbf{c g})$, showing areas of conspicuous pustulated ornamentation. Scale bars $=10 \mathrm{~mm}$. 
in the preoral region, is difficult to establish. The elements that form the endophragmal skeleton in other crustaceans have been interpreted as additional surfaces for muscular attachment or as support for the viscera, but their function remains poorly understood, even in extant species where it has been studied in detail (Guinot, pers. comm. 2010). This putative endophragmal skeleton is a distinctive feature of most specimens of Hoplita, but it seems to be absent in some

A

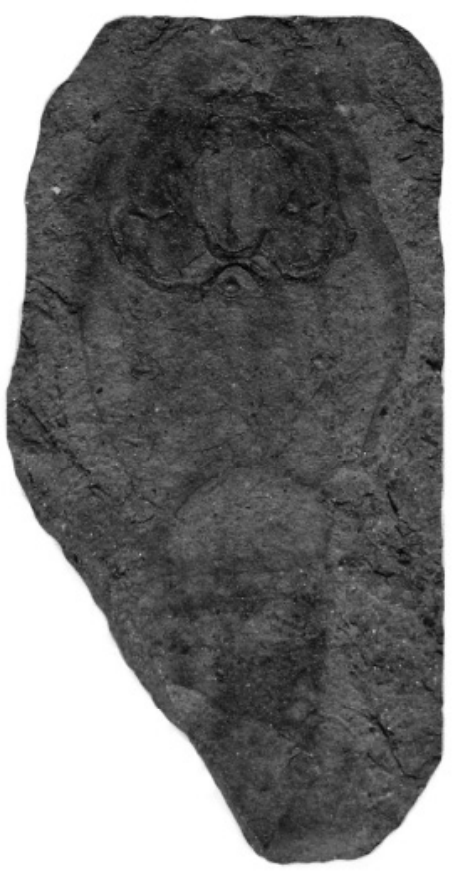

individuals (Figures 3A, 5C). This could be explained due to resorption in the pre-moulting stage (Greenaway, 1985) to facilitate mineral balance and the release of the old exoskeleton. Otherwise, it may be a taphonomic feature.

The pleon consists of six segments apparently bearing small pleopods as indicated by the pits observed laterally in each segment of some ventrally preserved individuals. Pleurae appear to be round (Figures 6B, 7A) in some individuals,
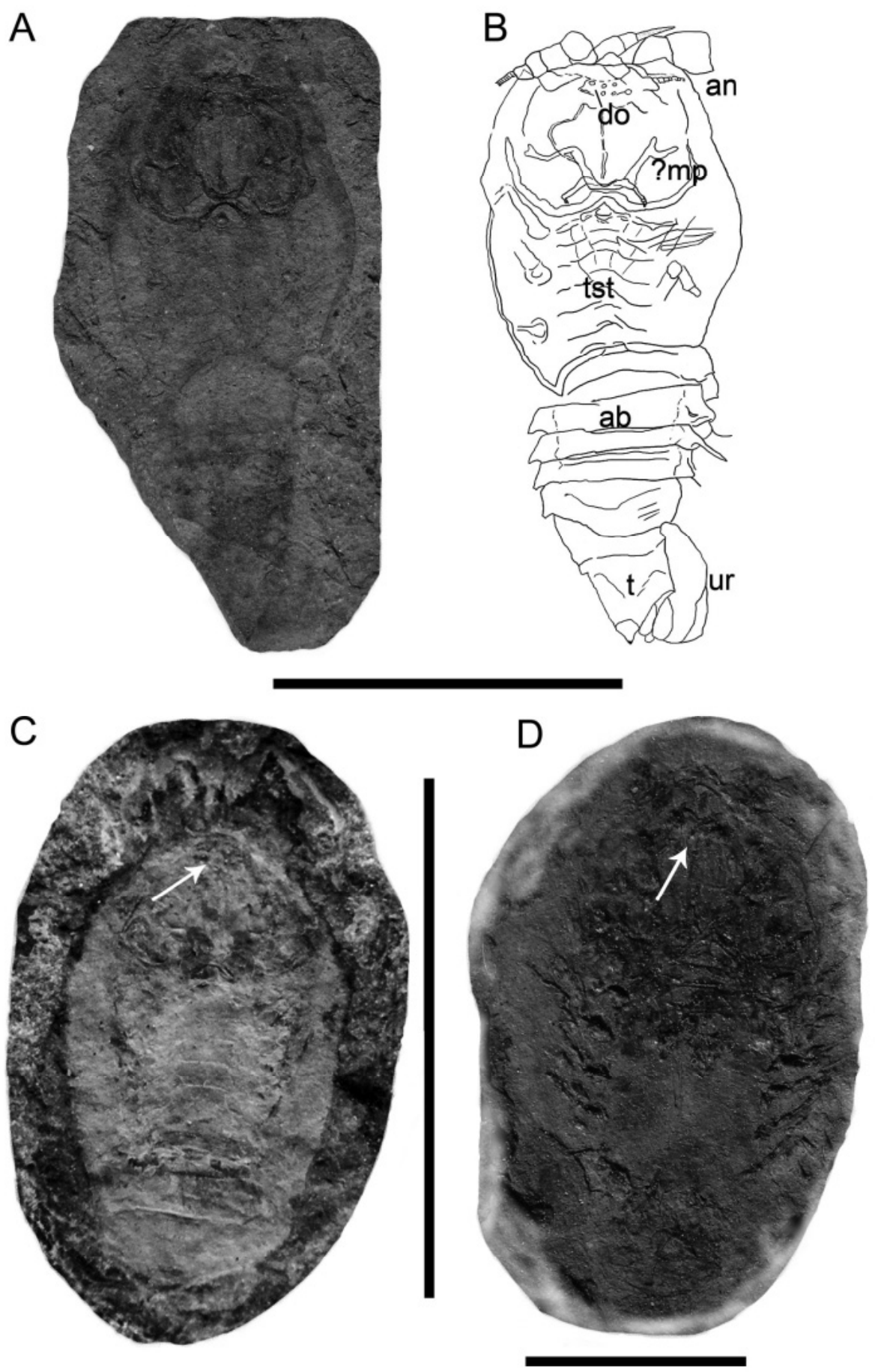

Figure 5. Hoplita ginsburgi comb. nov. Dorsal organ. A, FC-DPI 3553, almost complete compressed individual preserving a centrally placed anterior pitted area, here interpreted as the putative presence of a dorsal organ; B, schematic interpretive drawing of A; C-D, FC-DPI 4955 and 3930 respectively, showing equivalent pitted areas. Abbreviations: ab, pleon; an, antenna; do, dorsal organ; ?mp, putative maxillipeds; t, telson; tst, thoracic sternites; ur, uropods. Scale bars $=10 \mathrm{~mm}$. 


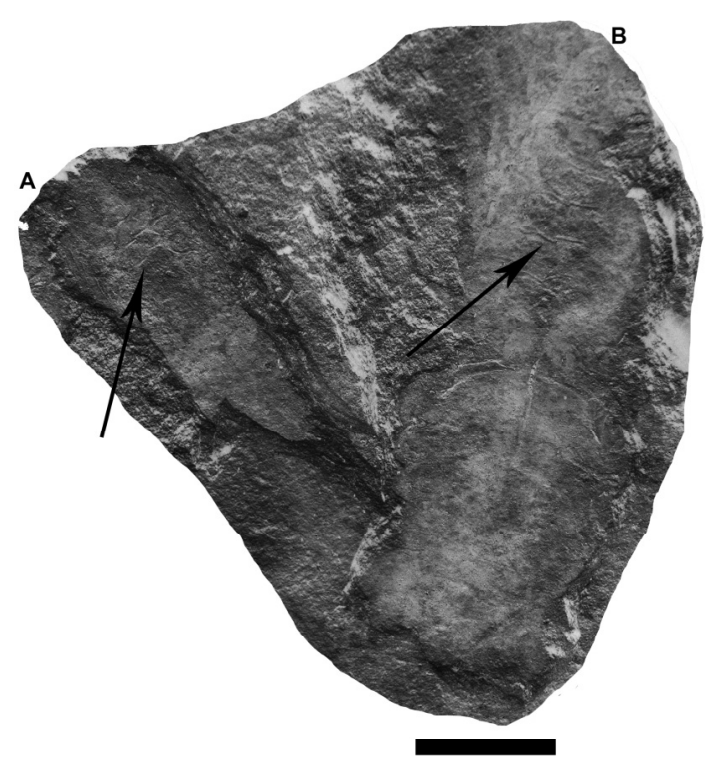

Figure 6. Hoplita ginsburgi comb. nov. Moulting evidence. A-B, FC-DPI 4950, two fragmentary specimens from the same slab showing inter-somite partitions not fused in the midline (arrows). This characteristic could suggest the presence of membranous articulation in life or the preservation of exuvia resulting from moulting specimens. Scale bars $=10 \mathrm{~mm}$. but sharply angular in others (Figures 7A, 7E). If this is not a taphonomic feature, this could reveal the presence of sexual dimorphism. Secondary sexual characters are difficult to identify in crustaceans (and obviously it is harder when dealing with fossils), but differences in pleural morphology were described for extant and fossil glypheids Glyphea regleyana Desmarest, 1822 and Neoglyphea inopinata Forest $\&$ de Saint Laurent, 1975, respectively (Forest \& de Saint Laurent, 1989; Feldmann \& de Saint Laurent, 2002), where the first four pleura of males are angular and pointed, while all the female pleura are round. Sexual dimorphism can be also observed in some compressed individuals that display the ventral surface of the body. Some of them show two anteriorly-directed, triangular structures, lying over the eighth thoracic somite (Figure 10A). These could be enlarged and modified swimmerets, joined at the mid-line of the segment in the way that male gonopods are usually placed in decapods. In decapods gonopods transfer sperm into the female receptacle for fecundation of the eggs. Other specimens preserve a roughly round structure in the central area of the eighth somite. Following Brooks (1962), we tentatively interpreted these round structures as female seminal receptacles (Figures 10 B-D). In counterpoint, Schram et al. (1986) postulated that

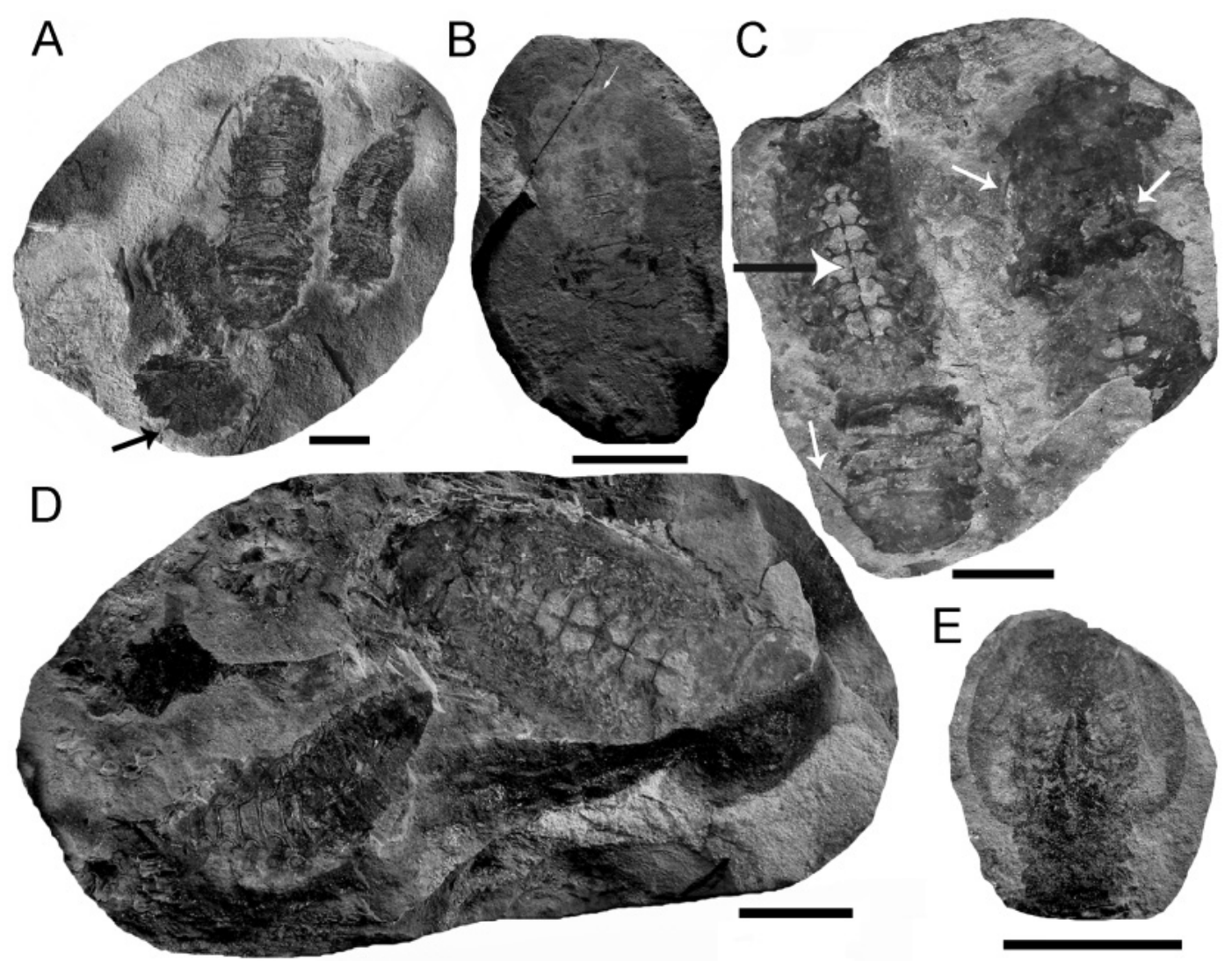

Figure 7. Hoplita ginsburgi comb. nov. Endophragmal skeleton and abdominal pleural spines. A, FC-DPI 4419, at least four individuals preserved together, carapace outline and endophragmal skeleton are not well displayed in all the specimens, but the abdominal spines can be seen in one of them (black arrow); B, FC-DPI 4599, an almost complete specimen showing the large cornea of the stalked eyes (white thin arrow); C, FC-DPI 4397, two no well preserved individuals showing clearly the thoracic endophragmal skeleton (combined white and black arrow) and the abdominal spine-like processes (white arrows); D, FC-DPV 4512, two incomplete specimens showing endophragmal skeleton, and the taphonomy-controlled, apparently different, elongate carapace outline; E, FC-DPI 4961, an almost complete specimen showing internal anatomy (probable digestive glands) and sharp, more that round abdominal pleurae. Scale bars $=10 \mathrm{~mm}$. 


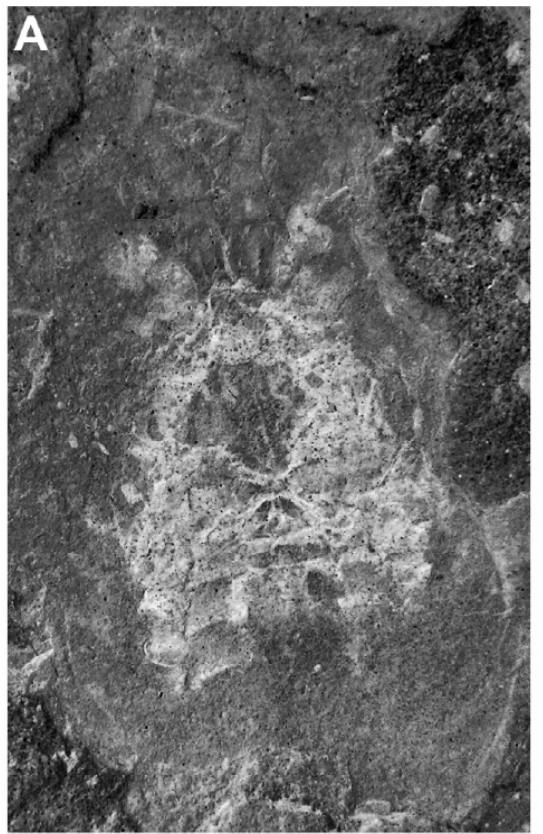

B

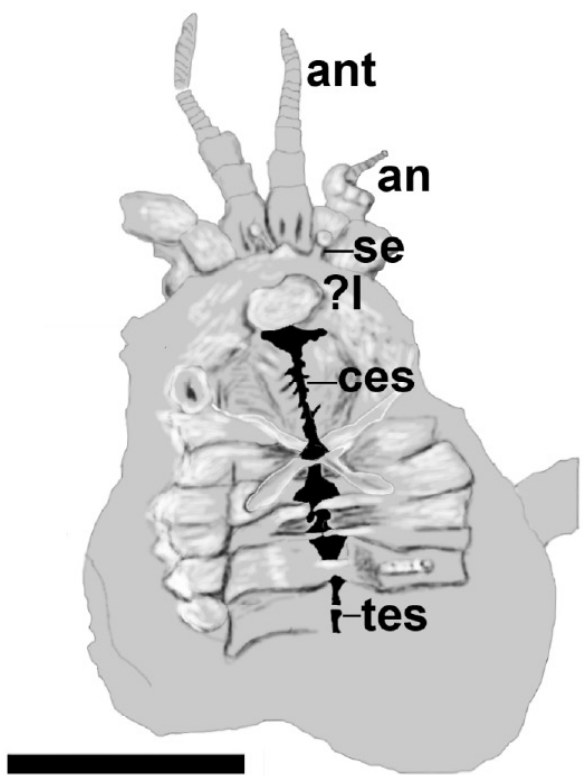

Figure 8. Hoplita ginsburgi comb. nov. Cephalic endophragmal skeleton. A, FC-DPI 3749, fragmentary anterior region preserving the cephalic portion of the endophragmal skeleton; B, schematic drawing of A to enhance the internal skeleton (in black). Abbreviations: an, antenna; ant, antennules; ces, cephalic endophragmal skeleton; ?I, putative labrum; se, stalked eyes; tes, thoracic endophragmal skeleton. Scale bar = $10 \mathrm{~mm}$.
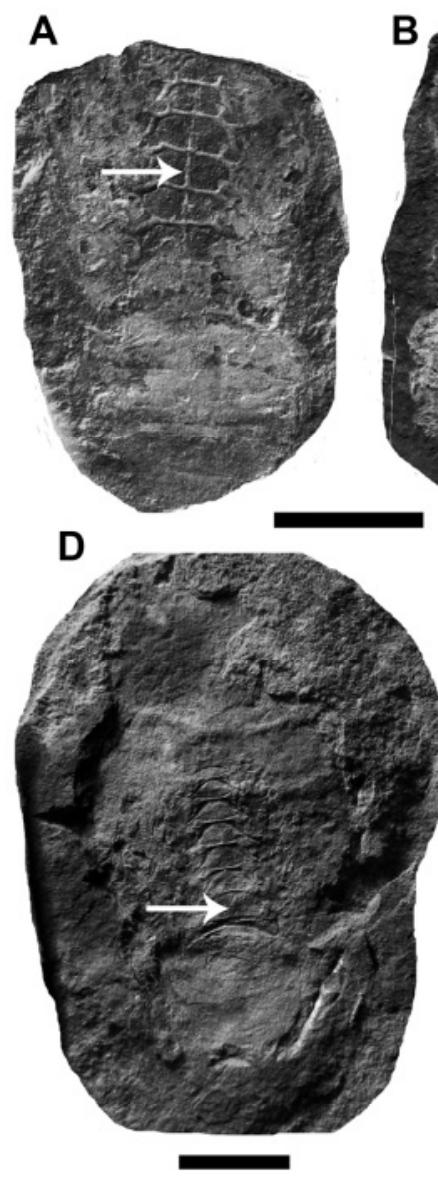

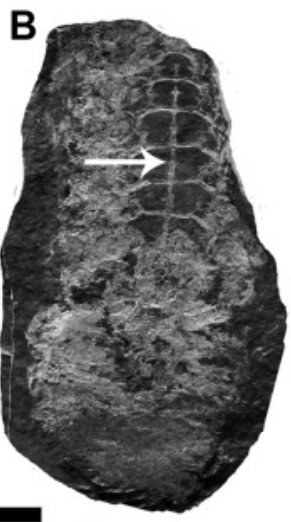

E

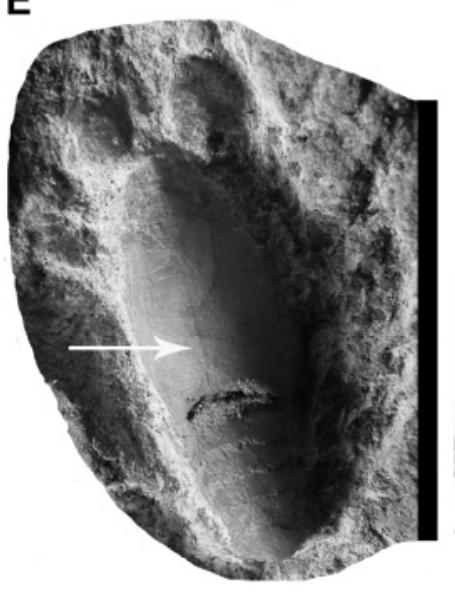

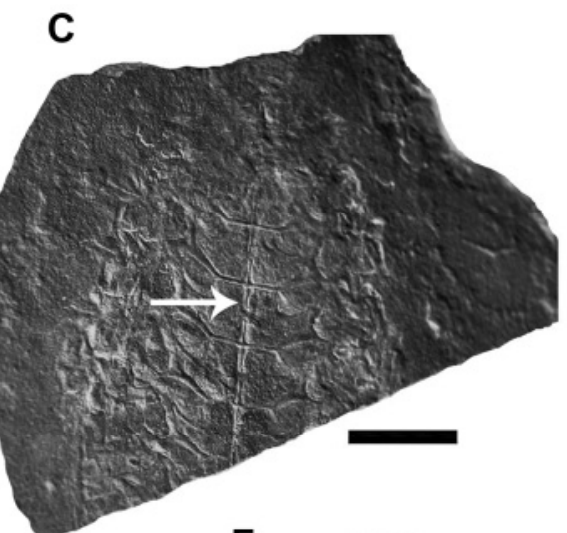

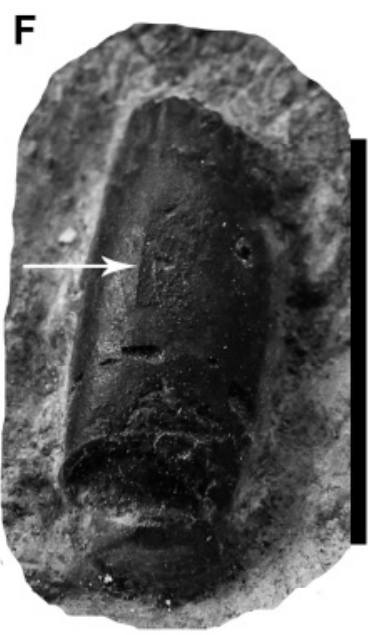

Figure 9. Hoplita ginsburgi comb. nov. Thoracic endophragmal skeleton. A-B, FC-DPI 3732 part and counterpart of a compressed individual respectively; C, FC-DPV 4838; D, FC-DPI 4518; E, FC-DPI 4959; F, FC-DPI 4956, compressed and three-dimensional specimens showing presence of thoracic endophragmal skeleton (arrows). In $E$ and $F$, the endoskeleton is visible as a false dorsal discontinuous carina (see text for more detailed references). Scale bars $=10 \mathrm{~mm}$. 


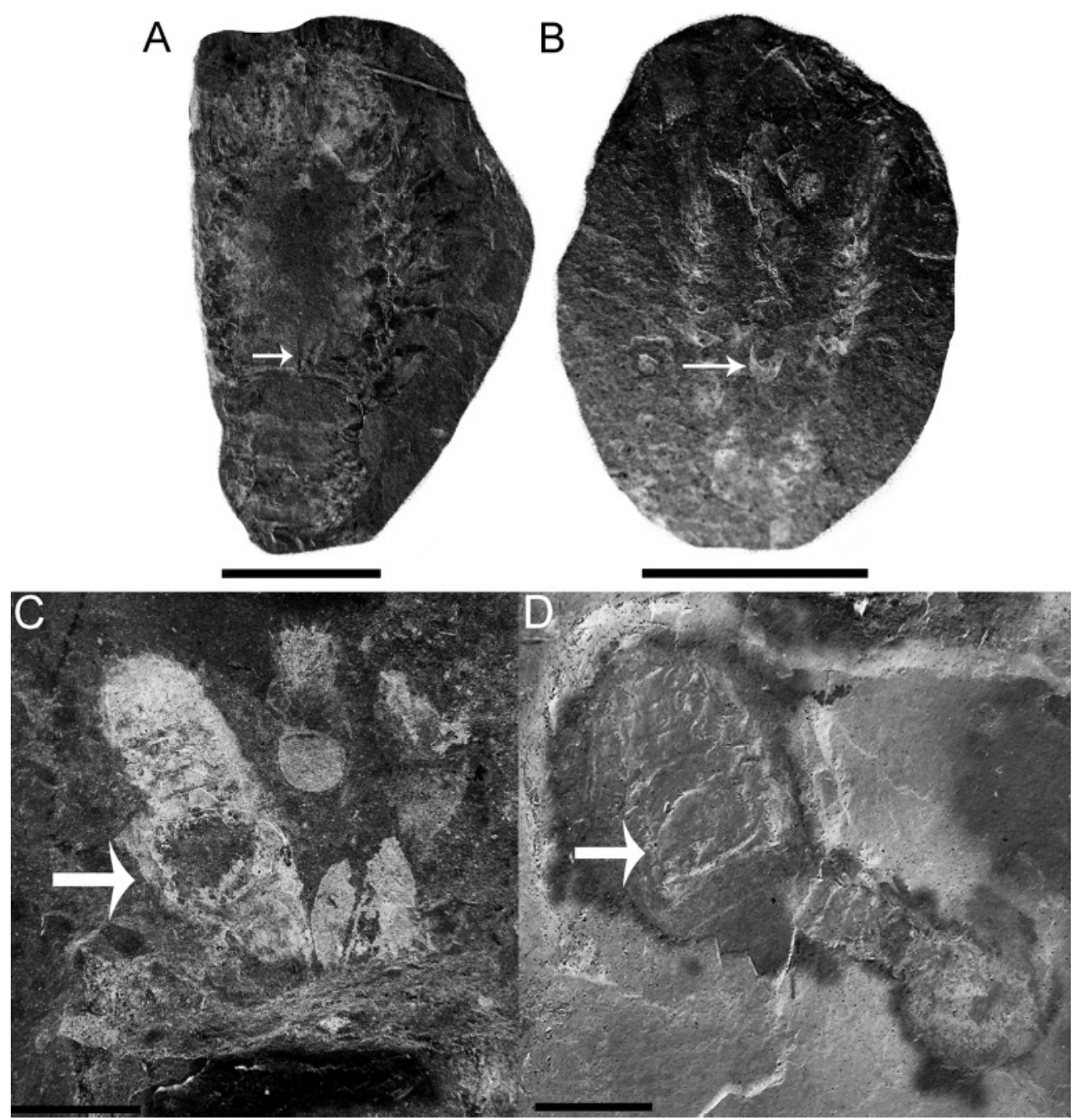

Figure 10. Hoplita ginsburgi comb. nov. Sexual dimorphism. A, FC-DPI 3817, putative male specimen showing sexual swimmerets joined at the midline at the level of eighth thoracic segment (white arrow); B, FC-DPI 3803; C, FC-DPI 4824; D, FC-DPI 4383, putative female specimens showing round central depressions in the middle of the eighth sternite, suggesting the presence of seminal receptacles (white arrows). Scale bars $=10 \mathrm{~mm}$.

the round structures could be similar to the cone present in tanaidaceans where monokonophoric and dikonophoric structures are known to occur. We deem the Brooks (1962) hypothesis more plausible, as the materials suggest. Thus, the dimorphic morphologies of Hoplita are more similar to those of decapod crustaceans than to peracarids, where a marsupium supported by thoracic oostegites is developed. Pleural morphology does seem to show differences between these specimens: round in putative females and sharp in males.

Slender, spine-like projections can be seen on the pleon of some individuals (Figures 7A, 7C). It is possible to ascertain that some of these display dorso-laterally spinelike projections in certain segments. Unfortunately it is not possible to verify from available specimens if spines are present in all somites or just in the anteriormost ones. In any case, spines should be considered as a distinctive character for this taxon, even if they are associated with sexual dimorphism (which could not be demonstrated from the studied materials). The reflexion of the pleon under the thorax may produce the retraction of the spines, and thus, they could only be visible in some specimens that preserve the pleon more or less extended. The tail fan is not particularly distinctive (Figures 5A-B, 11); the telson is a sub-trapezoidal plate (as it is in Pygaspis, Notocaris, Anthracaris and Pygocephalus) with small lateral spines and a triangular and lobe-like caudal spine. Secondary lateral spine-like processes could have been present (as in Anthracaris and Pygocephalus) but they clearly are less conspicuous. The uropods are biramous with bladelike exopods and larger round endopods that lack diareses.

\section{Internal morphology}

Some organs of the digestive tract can be seen on the best preserved specimens. Both the pyloric and gastric stomachs (Piñeiro et al., 2012), and the posterior intestine can be detected in some well preserved and compressed specimens so that is possible to see the impressions of the muscular fibers of the midgut (Figure 12). As explained above, putative sexual structures were detected in some specimens (e.g. the presence of seminal receptacles and gonopods). These structures of the internal anatomy will be described in more detail in a forthcoming paper. 


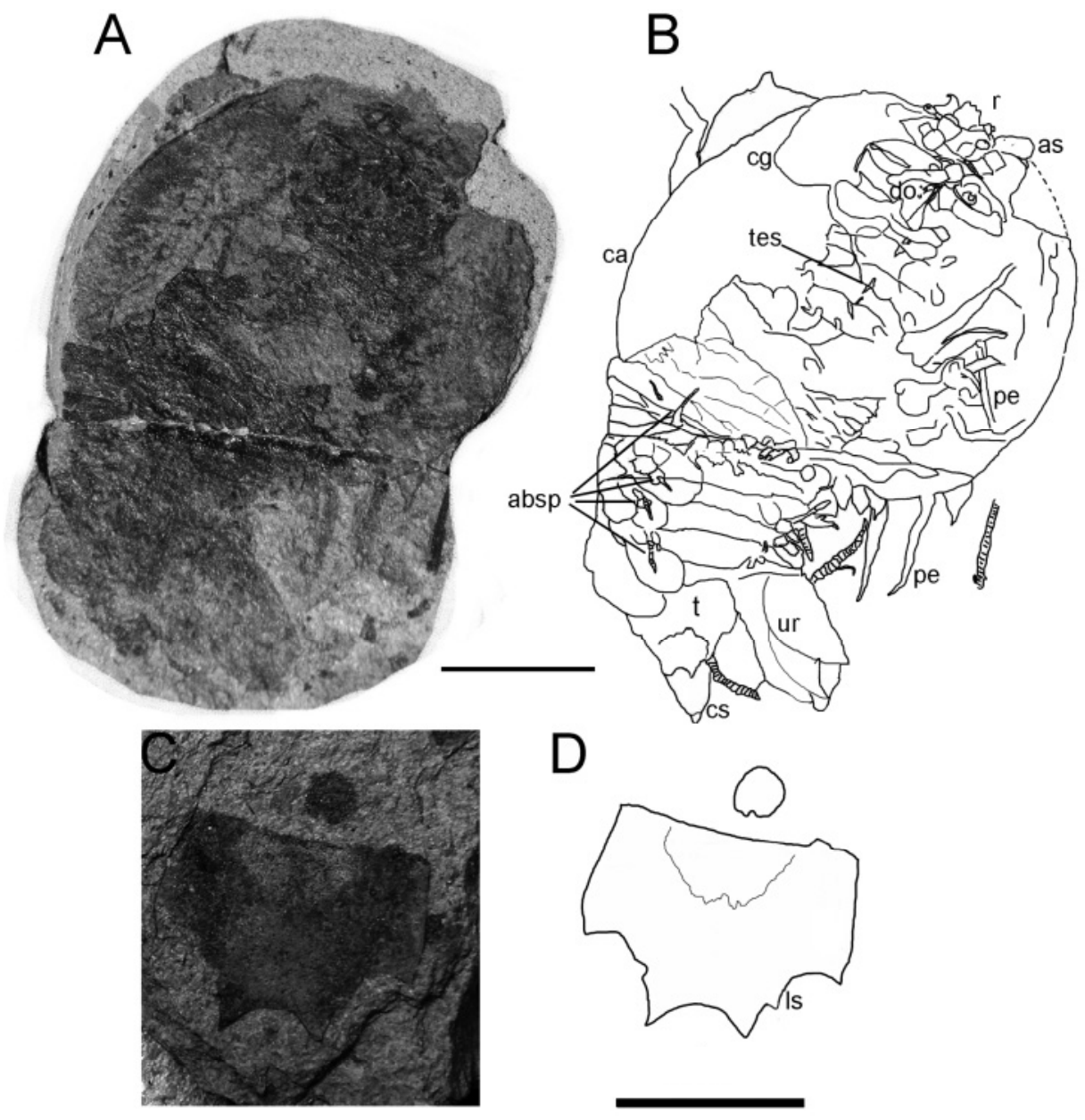

Figure 11. Hoplita ginsburgi comb. nov. Telson morphology. A, FC-DPI 4345, a well preserved large compressed individual, showing almost all the characters that characterize Hoplita: round carapace, endophragmal skeleton, abdominal spines and the trapezoidal shape of the telson; B, interpretive drawing of A; C, FC-DPI 3809, isolate telson showing clearly its trapezoidal shape and the spine-like processes (Is) developed laterally to the caudal spine, which is not preserved in this specimen; D, interpretive drawing of C. Abbreviations: absp, abdominal spines; as, antennal scale; ca, carapace; cg, cervical groove; cs, caudal spine; do, dorsal organ; Is, lateral telson spines; pe, pereiopods; $\mathbf{r}$, rostrum; t, telson; tes, thoracic endophragmal skeleton; ur, uropods. Scale bars: A-B $=10 \mathrm{~mm}$; C-D $=5 \mathrm{~mm}$.

\section{DISCUSSION}

\section{Critical review of the diagnostic characters for identification of the taxa and intervening taphonomic processes}

Most of the systematic and phylogenetic studies on Pygocephalomorpha are based on Laurasian taxa, mainly due to the lack of knowledge of the Gondwanan species. This study constitutes a preliminary effort to explain some of the main problems revealed during the study of Uruguayan pygocephalomorphs, in order to eventually lead to a better understanding of their affinities.

One of the major problems that we had to deal with was the recognition of the diagnostic characters used to support the currently established pygocephalomorph families in the new fossil specimens. Preservation of the specimens as three-dimensional or compressed individuals is the main problem in taxonomy. If the diagnoses of taxa are based on holotypic specimens preserved as three-dimensional, dorsal views of the body, it will be difficult to evaluate these characters in specimens with ventral exposure and viceversa. This is particularly vexing if we take into account that several Gondwanan taxa have been erected on the basis of dorsal characters based only on the carapace, with nothing known about features of pleon or the tail fan (e.g. Liocaris). In addition, most specimens from shales (dorso-ventrally compressed specimens or impressions of the dorsal, lateral or ventral surfaces of the body) are preserved as part and counterpart of the same individual. These can present different morphologies (e.g. shape of thoracic somites, shape of the cervical groove and general carapace outline). Thus, finding them as isolated elements can lead to incorrect or incomplete diagnoses and inaccurate taxonomic identifications.

Below, we present a succinct examination of some of the characters previously used to discriminate pygocepalomorph species, and we describe the difficulties we found trying to use them in the classification of the specimens found in the Mangrullo Formation of Uruguay. The taxonomic value of some characters will depend on their resistance to taphonomic processes (the less affected) and their easy recognition on the preserved specimens. However, it is important to note that the best taxonomic assignation is that which can be based on a combination of characters. Thus, erection of new species 

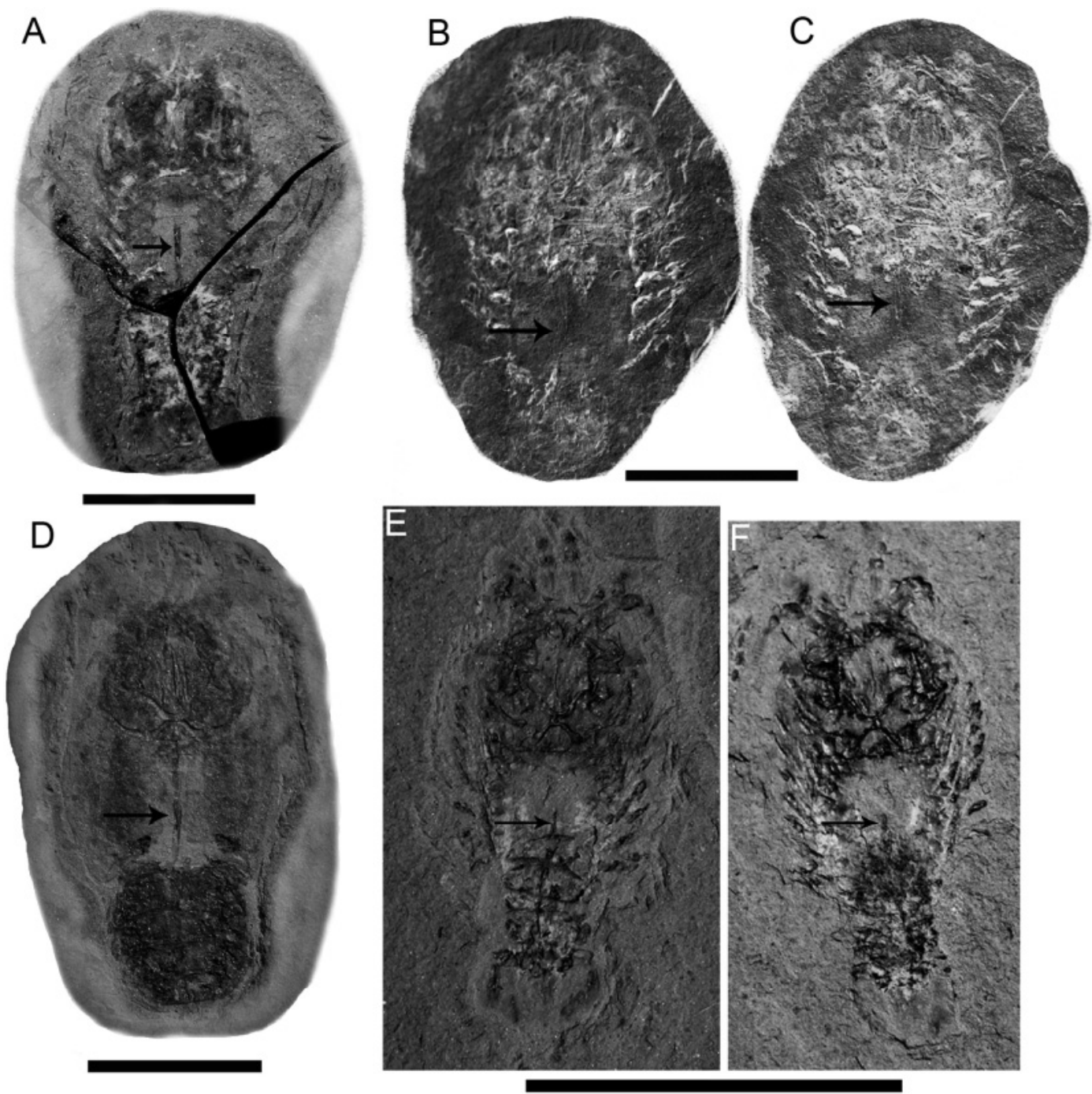

Figure 12. Hoplita ginsburgi comb. nov. Internal anatomy. A, FC-DPI 3725; B-C, part and counterpart of FC-DPI 3930; D, FC-DPI 3542; E-F, part and counterpart of FC-DPI 3559. All these specimens preserved the impression of midgut muscular fibres (black arrows) suggesting rapid burrowing in anoxic environment where decomposition rates is very low. Scale bars $=10 \mathrm{~mm}$.

using incomplete materials should be avoided in the future, especially when specimens lack a sufficient number of visible characters (Schram, pers. comm. 2011).

\section{Marginal spines}

The verification of anterolateral or lateral spines on the carapace margin usually becomes a difficult issue, particularly when the specimens are poorly preserved or the lateral margins are hidden by ventral bending. In this respect, Paulocaris and Notocaris from Permian deposits of Brazil and South Africa, respectively, provide good examples. Before Brooks (1962), Paulocaris was described by several authors as having a carapace with anterolateral spines (Clarke, 1920; Beurlen, 1931; Mezzalira, 1954). Kensley (1975) noticed the presence of anterolateral and lateral spines in Notocaris, a taxon which had been described by Broom (1931) as lacking marginal spines. Such a contradiction can be attributed to taphonomy. The significance of the character "absence or presence of marginal spines" can be seen in the phylogenetic analysis performed by Taylor et al. (1998), including all major pygocephalomorph clades. That analysis indicated that this character is variable within Pygocephalomorpha. The Pygocephalidae could be characterized by the presence of marginal (lateral and anterolateral) spines, but the absence of such spines could not diagnose all of the remaining pygocephalomorph clades. Tylocarididae, some components of Tealliocarididae (Brooks, 1962) and some members of Notocarididae, have anterolateral spines (Clarke, 1920; Taylor et al., 1998; this work).

\section{Pleon extended versus pleon reflected}

Other contradictions in the literature were also detected regarding the disposition of the pleon. Brooks (1962) placed Notocaris and Paulocaris in his new taxon Notocarididae based on the presence of a reduced and ventrally flexed pleon. However, only one specimen of Paulocaris preserves an incomplete pleon (Mezzalira, 1954), and it is neither reflected nor reduced. Moreover, Notocaris was described by Broom (1931) with a flexed pleon, but a later study (Kensley, 1975) illustrated specimens with either an extended or flexed pleon. Thus, one wonders if the validity of this character can 
be subjected to different taphonomic expressions or does it represent a genunine anatomical condition in some species. This question requires a more rigorous study evaluating a larger number of specimens. The analysis of this character in the Uruguayan pygocephalomorphs suggests that the use of this character to diagnose any taxon should be limited. Based upon the specimens of Hoplita ginsburgi comb. nov. described herein, the pleon is preserved extended (e.g. see Figures 5A-B; 12A, E-F), or flexed (e.g. Figures 2; 5B-C), thus suggesting it is a taphonomic feature. Even so, some extant lobster-like creatures (including crayfishes) carry the pleon flexed to some degree, a configuration that could play a role in distinct preservations of the pygocephalomorph pleon (Schram, pers.comm. 2011).

\section{Carapace shape}

The carapace outline is a character of limited use for taxonomic purposes, at least concerning Gondwanan pygocephalomorphs. The carapace is a delicate, thin structure, and not easily detected in most the dorso-ventrally compressed specimens. Moreover, the lateral margins are frequently ventrally bent, which makes it difficult to distinguish those specimens in which the carapace appears as a round structure. Therefore, it is problematic to discriminate between taxa using this character exclusively.

\section{Cervical groove shape}

The impression and shape of the cervical grooves is a good marker with which to evaluate taxonomic assignment. It is generally well delimited in dorsally preserved individuals, but often it can be outlined in compressed specimens preserved in ventral view. In such cases the cervical grooves can be seen by superposition of ventral and dorsal surfaces.

\section{The morphology of the tail fan}

Although very difficult to ascertain in most individuals, whether three-dimensionally preserved or compressed, the morphology of the telson and the shapes of the lateral and apical spines (or lobes) could be key traits for identifying taxonomic differences and similarities between specimens that otherwise appear to be problematic. Nevertheless, there is a major problem in determining the morphology of the tail in Gondwanan pygocephalomorphs due to their tendency to flex the pleon. As mentioned above, we did not find reasons to consider this last condition as a genuine diagnostic character. Rather most of the specimens preserved the pleon more or less ventrally folded. Perhaps this signaled sudden mortality and rapid fossilization, but it could also represent a genuine behavioral trait. Despite these problems, we strongly recommend tail fan traits to be placed in the list of useful characters to determine species. We have found these traits to be useful in the recognition of many Laurentian pygocephalomorph genera and species.

\section{Three-dimensional versus compressed specimens as indicator of specific habitat preferences}

In the study of Gondwanan pygocephalomorphs, we were able to associate preservation distinctions to habitat preferences. Three-dimensional specimens were only preserved in calcareous levels and bi-dimensional ones were found in shales. For instance, Liocaris was found only in limestones while Pygaspis was found only in shales of the Irati Formation in Brazil (Pinto \& Adami, 1998). Originally we thought that the species found in shales were unique to that facies, as were the species found only in carbonate facies. But after further examination we detected the characters that distinguish Hoplita ginsburgi comb. nov. in all of the sedimentary facies. We also realized that differences could be restricted just to size. Most of the specimens in the limestones are small compared to the larger ones in the shale. The other characters by which specimens could differ are not available for examination in most three-dimensional specimens. Such traits include the shape of the thoracic somites and the carapace outline, which is frequently distorted. However, we can see the presence of the endophragmal skeleton in some of these specimens, due to the extremely thin and transparent carapace structure (taking into account the postmorten, diagenetic mineralization of the specimens). Spectroscopic SEM analyses for mineralogical composition of the carapace showed no signs of mineralization in specimens from shales, but calcified and silicified carapaces were detected in three dimensional specimens from $\mathrm{Ca}$-rich and $\mathrm{Si}$-rich limestones respectively. We conclude that the same species can be found in lithologically different levels of the Mangrullo Formation in Uruguay, which surely exerted control on the preservation of the specimens due to the differences in their sedimentary chemistry.

\section{Phylogenetic relationships}

Taylor et al. (1998) provided a large scale phylogenetic analysis including recent "mysidacean" and lophogastrid taxa plus fossil pygocephalomorphs. That analysis recovered unresolved relationships for several Gondwanan taxa. This result was considered by Taylor et al (1998) to be a consequence of the inadequate knowledge we have about the anatomy of the southern species. In this respect the present study is a preliminary contribution and much work will be needed to solve the taxonomic confusion created by the fragmentary nature of many of the type specimens. Inadequate diagnoses and the lack of easily recognized characters, exacerbated by taphonomic processes that masked the true morphology of the specimens, led to incorrect identifications of several taxa. For this reason, a phylogenetic analysis was not included in this paper. We consider the status of several Gondwanan taxa (e.g. Pygaspis brasiliensis and Notocaris tapscotti) problematic.

\section{Paleoenvironments and paleobiology}

Uruguayan pygocephalomorphs are most frequently found closely associated with mesosaurid reptiles and the ichnogenus Chondrites. That means they formed part of a very unusual, low-diversity, aquatic community (Piñeiro et al., 2012). Some of the smallest pygocephalomorph specimens from marginal areas of the basin are found in association with a low-diversity plant assemblage along with homopteran and coleopteran 
insects (Pinto et al., 2000; Piñeiro, 2006). These associations indicate a lagoonal environment similar to that suggested for the Lower Permian Petrolia Formation of North America, where the pygocephalomorphs Mamayocaris serendipitous Hotton et al., 2002 and Paulocaris schrami Hotton et al., 2002 are associated with reptiles and plant debris. However, different than those in Uruguay, the assemblage in the Petrolia Formation includes also temnospondyls, fishes, and other arthropods (Hotton et al., 2002). The extremely low diversity of the Uruguayan pygocephalomorph assemblage, including a single dominant species, Hoplita ginsburgi comb. nov., is very unusual. This ecological oddity, added to sedimentological and mineralogical evidence from the enclosing rocks (including deposition of several levels of gypsum crystals), argue for increasing hypersaline conditions in the Mangrullo Formation when the mesosaurs and pygocephalomorphs coexisted (Piñeiro et al., 2012). This harsh environment was probably produced by diminution of the fresh water input by isolation and restriction of the basin along with the implantation of an arid climate by a reduction of rainy seasons, which consequently produced increasing rates of evaporation. The accumulation of large amounts of organic matter creating poorly oxygenated bottom conditions became inhospitable to life. However, it contributed to the excellent preservation of fossils and allowed for the description of the oldest known South American Konservat Lagersttäte (Piñeiro et al., 2012). Organisms living on the boundaries of such harsh environments likely needed to evolve some sorts of adaptive morphological and physiological traits. Perhaps the distinctive features of $H$. ginsburgi were related to the conditions at the bottom of the Mangrullo lagoon, selecting for the development of a large and elaborate extrinsic musculature, the type of arrangement that characterizes a reptant life-style as exemplified in extant lobsters.

\section{Paleobiogeography}

Leaving the phylogenetic relationships of Gondwanan pygocephalomorphs to be determined, the paleobiogeographical scenario outlined by the Taylor et al. (1998), deserves some comments. Considering both geographical and stratigraphical criteria, which indicate that all Carboniferous pygocephalomorph records come from the North Hemisphere (Schram, 1978; Taylor et al., 1998), a Laurasian origin for Pygocephalomorpha is well supported. Thereafter pygocephalomorphs could have dispersed to Gondwana some time close to the Permo-Carboniferous boundary or earlier (Taylor et al., 1998). Gondwanan pygocephalomorphs differ from Laurasian taxa (Pinto, 1972), but they share most of their primary characters. South African and South American pygocephalomorphs are so similar to one another that there is a growing acceptance that the same species was present on both continents (Pinto, pers. comm., 2010; this work) now separated due to continental drift.

As the Taylor et al. (1998) phylogeny shows, the relationships of the Gondwanan species Notocaris tapscotti, Pygaspis brasiliensis, and Hoplita ginsburgi comb. nov. remain poorly established. If they were basal taxa they could have been present in Gondwana some time earlier than the fossil record indicates. Otherwise they were the most derived pygocephalomorphs. Liocaris and Paulocaris are closely allied to the Chinese Late Carboniferous Chaocaris Shen Yan Bin, 1983 and the Permian Tylocarididae. This suggests a dispersal event, followed by speciation around the earliest Permian. Such a scenario could be summarized as follows: if the original pygocephalomorph communities have been restricted entirely to Euramerica during the Carboniferous, the dispersion at the end of that period could have been produced either from North America or from Eurasia, eventually reaching China. However, an alternative hypothesis might offer another dispersion event, one from Gondwana, inferred from the possible basal position of the South American and South African taxa. This significant, almost worldwide pygocephalomorph expansion was probably favoured by the incipient formation of the supercontinent Pangaea (Taylor $e t$ al., 1998), promoted by a physical connection between the fossiliferous strata (Scotese \& McKerrow, 1990).

The present report on relationships within Pygocephalomorpha is far from definitive. Much work is needed in the future, taking into account current anatomical constraints, to allow for a more comprehensive understanding of the interrelationships of its component taxa.

\section{CONCLUSIONS}

A study of several new pygocephalomorph specimens from the Early Permian Mangrullo Formation of Uruguay contributed to a better understanding of the poorly known Gondwanan representatives of this clade. Hoplita ginsburgi comb. nov. was recovered from shale and calcareous levels of the Mangrullo Formation of Uruguay. This species is also present in Lower Permian deposits of South Africa, reflecting a close connection of the basins at that time. This species is very peculiar in the development of an axial endoskeleton, a poorly known structure present in some malacostracan (chiefly decapod) crustaceans, but never previously described for any other pygocephalomorph. Sexual dimorphism and recognition of exuvia from living fossil individuals were two aspects suggested herein that constitute an original contribution to the study of South American pygocephalomorphs.

An analysis to investigate the phylogenetic relationships of Hoplita ginsburgi comb. nov. with other Gondwanan and Laurasian pygocephalomorphs is not possible at this stage of our knowledge, due to the confusing status of certain other Gondwanan taxa (e.g. Pygaspis brasiliensis and Notocaris tapscotti). In general, taxonomic problems resulting from a lack of diagnostic characters in the type specimens (Liocaris and Paulocaris) made worse by the effects of taphonomic processes leading to different interpretations of the same structure. Consequently, a careful morphological review of both South African and Brazilian specimen will be crucial to reconstructing the taxonomic and phylogenetic schema of Gondwanan pygocephalomorphs. Hopefully the resulting more complete scenario will encourage future research on this group of extinct crustaceans. 


\section{ACKNOWLEDGEMENTS}

We are greatly indebted to the Hastings family for their invaluable support and kindness over the years, as also to Yerú Pardiñas for his hospitality during our stays at the Agronomic Station of the Cerro Largo County. We are especially grateful to A. Mones for his helpful comments on taxonomic nomenclature. C. Goso, D. Picchi, F. Kuczera, and K. Bentos-Pereira assisted us in the field work. I. Castiglioni produced the illustrations. Reviewers F. Schram and R. Feldmann provided useful suggestions and comments that highly improved this work, and D. Peters revised the English for the final version of the manuscript. Support for this research was provided by grants from ANII, FCE 2007_96, and PEDECIBA Biología (Facultad de Ciencias) to G. Piñeiro and E. Morosi.

\section{REFERENCES}

Anderson, A. 1976. Fish trails from the Early Permian of South Africa. Palaeontology, 19:397-409.

Basei, M.; Rocha-Campos, A. \& Nutman, A. P. 2004. Idade e proveniência de zircões de rochas neopaleozóicas do Brasil: resultados preliminares. In: SIMPOSIO 40 ANOS DE GEOCRONOLOGIA NO BRASIL (USP), 2004. Boletim de Resumos, São Paulo, p. 9.

Beurlen, K. 1930. Vergleichende Stammesgeschichte Grundlagen, Methoden, Probleme unter besonderer Berüksichtigung der höheren Krebse. Fortschriften der Geologie und Palaeontologie, 8:317-464.

Beurlen, K. 1931. Crustacean reste aus den Mesosaurierschichten (Unterperm) von Brasilien (Sao Pulo). Paleontologische Zeitsckrift, 13:35-50.

Beurlen, K. 1934. Die Pygaspiden, eine neue Crustaceen (Entomostracen) Gruppe aus den Mesosaurier-führenden iratíSchichten Brasiliens. Paleontologische Zeitsckrift, 16:122-138.

Beurlen, K. 1953. O gêneno Paulocaris Clarke nas camadas Irati do Brasil Meridional. Notas Preliminares e Estudos, Divisão de Geologia e Mineralogia, DNPM, 65:1-8.

Beurlen, K. 1957. Faunas salobras fósseis e tipo ecológico-paleogeográfico das faunas gondwânicas no Brasil. Anais da Academia Brasileira de Ciências, 29:229-241.

Bossi, J. \& Navarro, R. 1991. Geología del Uruguay. Montevideo, Universidad de la República, $970 \mathrm{p}$.

Broom, R. 1931. On the Pygocephalus-like crustacean of the South African Dwyka. Proceedings of the Zoological Society, 2:571-573.

Bromley, R.G. \& Ekdale, A.A. 1984. Chondrites, a trace fossil indicator of anoxia in sediments. Science, 224:872-874.

Brooks, H.K. 1962. The Paleozoic Eumalacostraca of North America. Bulletins of American Paleontology, 44:163-338.

Clarke, J.M. 1920. Crustacea from the Permian of São Paulo, Brazil. Bulletin of the New York State Museum, 219/220:135-137.

Daemon, R.F. \& Quadros, L.P. 1970. Bioestratigrafia do Neopaleozóico da Bacia do Paraná. In: CONGRESSO BRASILEIRO DE GEOLOGIA, 24, 1970. Anais, Brasília, p. 359-412.

De-Santa-Ana, H. \& Gutiérrez, P. 2000. Formación Mangrullo (Cuenca Norte, Uruguay): estratigrafía y recursos minerales asociados. Revista de la Sociedad Uruguaya de Geología, 7:2-14.

De Santa Ana, H.; Goso, C. \& Danners, G. 2006. Cuenca Norte: estratigrafía del Carbonífero y Pérmico. In: G. Veroslavsky; M. Ubilla \& S. Martínez (eds.) Cuencas Sedimentarias de Uruguay: Geología, Paleontología y Recursos Minerales, Paleozoico, DIRAC - Facultad de Ciencias, p. 147-208.
Desmarest, A.G. 1822. Les Crustacés proprement dits. In: Brongniart, A. \& Desmarest, A.G. (eds.), Histoire naturelle des Crustacés fossils. F. G. Levrault, p. 128-137.

Etheridge, R. 1877. On the occurrence of a Macrurous Decapod (Anthrapalaemon woodwardi sp. nov.) in the Red Sandstone or lowest group of the Carboniferous Formation in the South East of Scotland. Quarterly Journal of the Geological Society of London, 31: 863-878.

Fabre, J. \& Huard, D. 1967. Un arthropode nouveau des "Upper Dwyka Shales" Pygaspis ginsburgi nov. sp. Annales de Paleontologie (Invertebrés), 53:121-141.

Feldmann, R.M. \& De-Saint-Laurent, M. 2002. Glyphea foresti n. sp. (Decapoda) from the Cenomanian of Northern Territory, Australia. Crustaceana, 75:359-373.

Forest, J. \& De-Saint-Laurent, M. 1975. Présence dans la faune actuelle d'un représentant du groupe mésozoïque des Glyphéides: Neoglyphea inopinata gen. nov., sp. nov. (Crustacea Decapoda, Glypheidae). Académie des sciences de Paris, (D) 281:155-158.

Forest, J. \& De-Saint-Laurent, M. 1989. Nouvelle contribution à la connaissance de Neoglyphea inopianata Forest \& de Saint Laurent, à propose de la description de la femelle adulte. Résultats des campagnes Musorstom. Mémoires du Muséum National D'Historie Naturelle, 144:75-92.

Greenaway, P. 1985. Calcium balance and moulting in the Crustacea. Biological Review, 60:425-454.

Hotton, N.; Feldmann, R.M.; Hook, R.W. \& Dimichele, W.A. 2002. Crustacean-bearing continental deposits in the Petrolia Formation (Leonardian Series, Lower Permian) of North-Central Texas. Journal of Paleontology, 76:486-494. doi: 0022-3360/02/0076-486\$03.00

Huxley, T.H. 1857. Description of a new crustacean (Pygocephalus cooperi) from the Coal Measures. Quarterly Journal of the Geological Society, 13:363-369.

Kensley, B. 1975. Taxonomic status of the pygocephalomorphic crustacea from the Dwyca 'White Band' (Permo-Carboniferous) of South Africa. Annals of the South African Museum, 67:25-33.

Latrielle, P.A. 1802. Histoire naturelle générale et particulièr, des crustacés at des insects. 3. Paris, F. Dufort, 486 p.

Mackinnon, J.; De Santa Ana, H. \& Pessi, H. 1982. Contribución al conocimiento del Paleozoico Superior de la Cuenca Paraná en el Uruguay. IUGS, UNESCO, Montevideo, 5:1-30.

Martin, J.W. \& Laverack, M.S. 1992. On the distribution of the Crustacean dorsal organ. Acta Zoologica, 73:357-368.

Mezzalira, S. 1952. Clarkecaris novo gênero de crustáceo Syncarida do Permiano. Boletim da Sociedade Brasileira de Geologia, 1:46-51.

Mezzalira, S. 1954. Novas ocorrências de crustáceos fósseis da Formação Irati do Sul do Brasil. In: F.W. Lange (ed.) Paleontologia do Paraná, Comissão de Comemorações do Centenário do Paraná, p. 163-173.

Oelofsen, B. 1981. An anatomical and systematic study of the Family Mesosauridae (Reptilia, Proganosauria) with especial reference to its associated fauna and paleoecological environment in the Whitehill Sea. University of Stellenbosch, South Africa, Ph.D. Thesis, $250 \mathrm{p}$.

Oelofsen, B. \& Araújo, D. 1983. Paleoecological implications of the distribution of mesosaurid reptiles in the Permian Irati Sea (Paraná Basin), South America. Revista Brasileira de Geociências, 13:1-6.

Peach, B.N. 1883. Further reasearches among the Crustacea and Arachnida of the Carboniferous rocks of the Scottish Border. Proceedings of the Royal Society of Eddinburgh, 30: 511-529.

Peach, B.N. 1908. Monograph of the Higher Crustacea of the 
Carboniferous rocks of Scotland. Memoirs of the Geological Survey of Great Britain, Palaeontology, 82 p.

Pennant, T. 1777. Crustacea, Mollusca, Testacea. $4^{\mathrm{a}}$ ed. London, British Zoology, 236 p.

Pinto, I.D. 1960. Novos dados sobre a constituição, posição sistemática e distribuição paleogeográfica do gênero Pygaspis Beurlen. In: CONGRESO BRASILEIRO DE GEOLOGIA, 16, 1960. Resumos, Brasília, p. 61-62.

Pinto, I.D. 1971. Reconstituição de Pygaspis Beurlen, 1934 (Crustacea, Pygocephalomorpha). Sua posição sistemática, seu significado e de outros fósseis para o Gondwana. Anais da Academia Brasileira de Ciências, 43:387-401.

Pinto, I.D. 1972. Late Paleozoic insects and crustaceans from Paraná Basin and their bearing on chronology and continental drift. Anais da Academia Brasileira de Ciências, 44:248-258.

Pinto, I.D. \& Adami-Rodriguez, K.1996. Pygocephalomorph Crustacea. New data and interpretations, with emphasis on Brazilian and South African forms. Pesquisas, 23:41-50.

Pinto, I.D.; Piñeiro, G. \& Verde, M. 2000. First fossil insects from Uruguay. Pesquisas, 23:41-50.

Piñeiro, G. 2002. Paleofaunas del Pérmico-?Eotriásico de Uruguay. PEDECIBA, Universidad de la República, Tesis de Maestría, 195 p.

Piñeiro, G. 2004. Faunas del Pérmico y Permo-Triásico de Uruguay: Bioestratigrafia, Paleobiogeografia y Sistemática. PEDECIBA, Universidad de la República, Tesis de Doctorado, 215 p.

Piñeiro, G. 2006. Nuevos aportes a la Paleontología del Pérmico de Uruguay. In: G. Veroslavsky; M. Ubilla \& S. Martínez (eds.) Cuencas Sedimentarias de Uruguay: Geología, Paleontología y Recursos Minerales, Paleozoico, DIRAC - Facultad de Ciencias, p. $257-279$.

Piñeiro, G. 2008. Los mesosaurios y otros fósiles de fines del Paleozoico. In: D. Perea (ed.) Fósiles del Uruguay, DIRAC - Facultad de Ciencias, p. 179-203.

Piñeiro, G., Beri, A. \& Verde, M. 1998. Estudio de una asociación fosilífera de la Formación Mangrullo (Pérmico Tardío) del Uruguay. In: CONGRESO URUGUAYO DE GEOLOGÍA, 2, 1998. Resumenes, Punta del Este, p. 202-204.

Piñeiro, G.; Ramos, A.; Goso, C.; Scarabino, F. \& Laurin, M. 2012. Unusual environmental conditions produced a Konservat Lagerstätte from Uruguay. Acta Palaeontologica Polonica. doi:org/10.4202/app.2010.0113

Preamor, E.; Fischer, T.V. \& Souza, P.A. 2006. Palinologia da Formação Irati (Permiano Inferior da Bacia do Paraná), em Montividiu, Goiás, Brasil. Revista del Museo Argentino de Ciencias Naturales - Nova Serie, 8:221-230.
Runnegar, B. \& Newell, N.D. 1971. Caspian-like relict molluscan fauna in the South American Permian. Bulletin of the American Museum of Natural History, 146:1-66.

Santos, V.R.; Souza, P.A.; Souza-De-Alvarenga, C.J.; Dantas, E.L.; Pimentel, M.M.; De Oliveira, C.G. \& Araújo, L. 2006. Shrimp $\mathrm{U}-\mathrm{Pb}$ zircon dating and palynology of bentonitic layers from the Permian Iratí Formation, Paraná Basin, Brazil. Gondwana Research, 9:456-463. doi:10.1016/j.gr.2005.12.001

Schram, F. 1974a. Mazon Creek caridoid Crustacea. Fieldiana Geology, 30:9-65.

Schram, F. 1974b. Convergences between Late Paleozoic and modern caridoid Malacostraca. Systematic Zoology, 23:323-332.

Schram, F. 1978. Jerometichenoria grandis n. gen. n. sp. (Crustacea: Mysidacea) from the Lower Permian of the Soviet Union. Journal of Paleontology, 52:605-607.

Schram, F. 1979. British Carboniferous Malacostraca. Fieldiana Geology, 40:1-129.

Schram, F. 1980. Pygocephalus from the Upper Carboniferous of the Soviet Union. Journal of Paleontology, 54:50-56.

Schram, F. 1981. Late Paleozoic crustacean conmmunities. Journal of Paleontology, 55:126-137.

Schram, F., Sieg, J. \& Malzahn, E. 1986. Fossil Tanaidacea. Transactions of the San Diego Society of Natural History, 21:127-144.

Secretan-Rey, S. 2002. Monographie du squelette axial de Nephrops norvegicus (Linné,1758). Zoosystema, 24:81-176.

Shen Yan Bin 1983. Anew pygocephalomorph genus (Eumalacostraca) of Lower Carboniferous from Anhui. Acta Paleontologica Sinica, 22:663-668.

Scotese, C.R. \& Mckerrow, W.S. 1990. Revised world maps and introduction. In: W.S. McKerrow \& C.R. Scotese (eds.) Paleozoic paleogeography and biogeography. Memoirs of the Geological Society, 12:1-21.

Taylor, R.S.; Shen Yan Bin \& Schram, F. 1998. New pygocephalomorph crustaceans from the Permian of China and their phylogenetic relationships. Palaeontology, 41:815-834.

Taylor, R.S.; Schram, F. \& Shen Yan Bin. 2001. A new Upper Middle Triassic shrimp (Crustacea: Lophogastrida) from Guizhou, China, with discussion regarding other fossil "Mysidaceans". Journal of Paleontology, 75:310-318.

Zalán, P.V.; Wolf, S.; Conceição, J.C.J.; Marques, A.; Astolfi, M.A.; Vieira, I.S.; Appi, V.T. \& Zanotto, A. 1990. Bacia do Paraná. In: G.P. de Raya Gabaglia \& E.J. Milani (eds.) Origem e evolução das bacias sedimentares, Petrobrás, p. 135-168.

Received in September, 2011; accepted in January, 2012. 